\title{
DIAGNOSIS OF LEARNING DIFFICULTIES AND GUIDANCE LEARNING SERVICES TO SLOW LEARNER STUDENT
}

\author{
Ulfa Danni Rosada \\ Fakultas Keguruan dan Ilmu Pendidikan \\ Universitas Ahmad Dahlan \\ rosada_ulfa@yahoo.co.id
}

\begin{abstract}
The failure to the learning process to reach ketuntasan material may not be returned in one factor, but on several factors involved in the process of teaching and learning. In the process diagnosis a learning disability what is important is finding the difficulty and types of difficulty teaching improvements conducted by effectively. A diagnosis is finding the a learning disability students and determine the possibility of how to overcome by taking into account the factors that affect the success of learning activities.
\end{abstract}

Keywords: diagnosis, learning disability, student

\section{PENDAHULUAN}

Sekarang ini guru harus mampu bekerja bersama dengan berbagai ragam siswa. Pada masa lalu, siswa diidentifikasi memiliki masalah pembelajaran, siswa yang sekarang kita sebut anak yang luar biasa. Sekarang ini, banyak siswa luarbiasa menggunakan setidaknya sebagian hari (sekolah) bersama dengan guru reguler. Dalam kategori siswa luarbiasa adalah siswa dengan kelemahan (cacat) dan juga siswa cerdas. Banyak pendidik percaya bahawa anak diberi label berbeda dengan teman sebayanya secara permanen terstigmasi. Guru, teman, dan siswa sendiri men-set harapan prestasi yang dodasarkan pada label bukan pada individu. Guru yang percaya bahwa siswa memiliki beberapa bentuk masalah biasanya melihat perilaku siswa sebagai yang terganggu. Dengan kata lain, mempercayai sesuatu yang salah pada siswa mengakibatkan guru melihat lebih salah (Woolfolk, 2004)

Menurut Abdurrahman (1999)
pelayanan pendidikan bagi anak
berkesulitan belajar yang tidak didasarkan
atas landasan teoritik yang dapat
diandalkan mungkin bukan hanya tidak

efektif dan efisien untuk mencapai tujuan tetapi juga menimbulkan kerugian bagi anak. Sebagai sontoh, semua guru mengetahui bahwa motivasi dapat meningkatkan prestasi belajar siswa. Tetapi, tidak banyak guru yang mengetahui bahwa bagaimana membangkitkan motivasi belajar anak. Dalam kelas yang siswanya memiliki kemampuan heterogen misalnya, mungkin guru akan menciptakan interaksi belajar yang kompetitif karena ia beranggapan bahwa kompetisi dapat meningkatkan motivasi yang pada gilirannya juga meningkatkan prestasi belajar anak.

Guru tersebut adakalanya lupa bahwa kompetisi antarindividu yang memiliki kekuatan tidak seimbang dapat menimbulkan ketidakberdayaan yang dipelajari bagi yang lemah dan menimbulkan kebosanan bagi yang terlalu kuat. Jika anak berkesulitan belajar berada dalam kelas dengan suasana belajar kompetitif semacam itu maka dapat diramalkan bahwa mereka akan menjadi putus asa, yang tidak hanya berakibat buruk pada pencapaian prestasi belajar yang optimal tetapi juga berakibat buruk 
bagi pembentukan kepribadiannya. Wlodkowski (2004) mengatakan guru yang mengajar hendaknya menjadi pendidik yang sangat mumpuni dan bahkan ketika menggunakan metode lain untuk menarik siswa dengan mencatat ketika guru mengajar meningkatkan kemajuan siswa karena siswa lebih memperhatikan dan mentransformasikan informasi ke dalam kata-katanya sendiri. Oleh karena itu, guru perlu memiliki pengetahuan teoretik yang dapat digunakan sebagai bekal dalam menciptakan strategi pembelajaran yang tidak hanya efektif untuk mencapai tujuan pembelajaran tetapi juga efektif untuk membangun kepribadian yang sehat pada anak.

\section{Menurut Makmun (2009)} meskipun para guru telah berusaha melancarkan segala kompetensi (antara lain menguasai bahan, memahami sasaran didik, mengelola program, menggunakan strategi dan metode, mengelola kelas serta kegiatan belajar mengajar dengan menggunakan alat bantu), namun tatkala sampai pada suatu saat harus melakukan evaluasi berdasarkan data dan informasi hasil pengukuran proses dan produl balajar, maka para guru diharapkan kepada beberapa kenyataan antara lain : (1) dengan menggunakan criterion referenced evaluation (CRE),

berdasarkan kapasitas (tingkat kecerdasan dan bakat) siswa sendiri untuk pelajaran dalam bidang studi tertentu dengan asumsi kondisi belajar telah disesuaikan dengan perbedaan-perbedaan individual, (3) berdasarkan waktu yang diterapkan (time allowed) untuk menyelesaikan suatu program belajar dengan asumsi bahan dan kondisi belajar diperkirakan sesuai dengan ketentuan waktu tersebut, (4) dengan menggunakan norm referenced (PAN) dimana seorang prestasi siswa dibandingkan prestasi siswa lainnya.

Bimbingan menurut Hamalik (2010) adalah proses pemberian bantuan terhadap individu untuk mencapai pemahaman dan pengarahan diri yang dibutuhkan untuk melakukan penyesuaian diri secara maksimum terhadap sekolah, keluarga, serta masyarakat. Baik sebagai pengajar maupun sebagai pembimbing, pada hakikatnya saling berkaitan satu sama lain. Dalam keseluruhan proses pendidikan guru merupakan faktor utama. Sehubungan dengan peranannya sebagai pembimbing, seorang guru harus : (1) mengumpulkan data tentang siswa, (2) mengamati tingkah laku siswa dalam situasi sehari-hari, (3) mengenal para siswa yang memerlukan bantuan khusus, (4) mengadakan pertemuan hubungan dengan orangtua siswa, baik secara individu maupun secara kelompok, (5) bekerja sama dengan masyarakat dan lembaga-lembaga lainnya untuk membantu memecahkan masalah siswa, (6) membuat catatan pribadi siswa, (7) menyelenggarakan bimbingan kelompok atau pribadi, (8) bekerja sama dengan petugas-petugas bimbingan lainnya untuk membantu memecahkan masalah para siswa, (9) menyusun program bimbingan sekolah bersama-sama dengan petugas bimbingan lainnya, (10) meneliti kemajuan siswa, baik di sekolah maupun di luar sekolah.

\section{HASIL DAN PEMBAHASAN Makna Belajar}

Belajar adalah suatu kata yang sudah akrab dengan semua lapisan masyarakat. Bagi para pelajar atau mahasiswa kata "belajar" merupakan kata yang tidak asing. Bahkas sudah merupakan bagian yang tak terpisahkan bagi semua kegiatan mereka dalam menuntut ilmu di lembaga pendidikan formal. Kegiatannya pun dapat dilakukan sesuai dengan keinginan mereka, baik diwaktu pagi hari, siang, sore, maupun pada malam hari.

Cronbach (dalam Djamarah : 2011) berpendapat bahwa learning is shown by 
change in behavior as a result of experience. Belajar sebagai suatu aktivitas yang ditunjukkan oleh perubahan tingkah laku sebagai hasil dari pengalaman. Belajar adalah perubahan yang relatif permanen dalam perilaku atau potensi perilaku sebagai hasil dari pengalaman atau latihan yang diperkuat.

Howard L. Kingskey (dalam Djamarah : 2011) mengatakan bahwa learning is the process by which behavior (in the broader sense) is origanated or changed through practice or training. Balajar adalah proses dimana tingkah laku (dalam arti luas) ditimbulkan atau diubah melalui praktik atau latihan.

Belajar menurut Sarwono dalam Khairani (2013), adalah suatu proses dimana tingkah laku ditimbulkan atau diperbaiki melalui serentetan reaksi atau situasi (atau rangsangan) yang terjadi.

Perubahan yang terjadi dalam diri seseorang banyak sekali baik sifat maupun jenisnya karena itu sudah tentu tidak setiap perubahan dalam diri seseorang marupakan perubahan dalam arti belajar.

Dengan demikian, dapat disimpulkan bahwa belajar adalahsemua aktivitas mental atau psikis yang dilakukan oleh seseorang sehingga menimbulkan perubahan tingkah laku yang berbeda antara sesudah belajar dan sebelum belajar.

\section{Makna Diagnosis Kesulitan Belajar}

Diagnosis, merupaka istilah teknis yang kita adopsi dari bidang medis. Menurut Thorndike dan Hagen (1955:530532) dalam Makmun (2012), diagnosis dapat diartikan sebagai : (1) upaya atau proses menemukan kelemahan atau penyakit apa yang dialami seseorang dengan melalui pengujian dan studi seksama mengenai gejala-gejalanya, (2) studi yang seksama terhadap fakta tentang suatu hal untuk menemukan karakteristik atau kesalahan-kesalahan dan sebagainya yang esensial, (3) keputusan yang dicapai setelah dilakukan suatu studi yang seksama atas gejala-gejala atau fakta tentang suatu hal.

Pekerjaan diagnosis bukan hanya sekedar mengidentifikasi jenis dan karakteristiknya, serta latar belakang dari suatu kelemahan atau penyakit tertentu, melakinkan juga mengimplikasikan suatu upaya untuk meramalkan kemungkinan dan menyarankan tindakan pemecahannya.

Pada umumnya 'kesulitan" merupakan suatu kondisi tertentu yang ditandai dengan adanya hambatanhambatan dalam kegiatan mencapai tujuan, sehingga memerlukan usaha lebih giat lagi untuk dapat mengatasi. Menurut Mulyadi (2010), Kesulitan belajar dapat diartikan sebagai suatu kondisi dalam suatu proses belajar yang ditandai adanya hambatan-hambatan tertentu untuk mencapai hasil belajar. Hambatanhambatan ini mungkin disadari dan mungkin juga tidak disadari oleh orang yang mengalaminya, dan dapat bersifat sosiologis, psikologis ataupun fisiologis dalam keseluruhan proses belajarnya.

Kesulitan belajar pada dasarnya suatu gejala yang nampak dalam berbagai jenis manifestasi tingkah laku baik secara langsung ataupun tidak langsung. Gejala ini akan nampak dalam aspek-aspek kognitif, motoris, dan afektif baik dalam proses maupun hasil proses maupun hasil belajar yang dicapai.

Menurut Syah (2003), diagnostik kesulitan belajar adalah langkah - langkah dalam upaya penentuan secara ilmiah jenis - jenis gangguan yang menyebabkan siswa gagal mencapai tujuan yang dipersyaratkan dalam proses pembelajaran, ditinjau dari tujuan pendidikan, kedudukan dalam kelompok, perbandingan antara potensi dengan prestasi, dan kepribadiannya, agar 
perbaikannya dapat dilakukan secara efektif.

Disetiap sekolah dalam berbagai jenis dan tingkatan pasti memiliki anak didik yang berkesulitan belajar. Masalah yang satu ini tidak hanya dirasakan oleh sekolah modern di perkotaan, tapi juga dimiliki oleh sekolah tradisional di pedesaan dengan segala keminiman dan kesederhanaannya. Hanya yang membedakannya pada sifat, jenis, faktor penyebabnya.

Suatu pendapat yang keliru dengan mengatakan bahwa kesulitan belajar anak didik disebabkan rendahnya inteligensi. Karena dalam kenyataannya cukup banyak anak didik yang memiliki inteligensi yang tinggi, tetapi hasil belajarnya rendah, jauh dari yang diharapkan. Dan masih banyak anak didik dengan inteligensi yang ratarata normal, tetapi dapat meraih prestasi belajar yang tinggi melebihi kepandaian anak didik dengan kepandaian anak didik dengan inteligensi yang tinggi. Tetapi juga disangkal bahwa inteligensi yang tinggi memberi peluang yang besar bagi anak didik untuk meraih prestasi belajar yang tinggi. Oleh karena itu, selain faktor inteligensi, faktor non inteligensi juga diakui dapat menjadi penyebab kesulitan belajar bagi anak didik dalam belajar. (Djamarah :2011).

Menurut Mulyadi (2010) ada ciriciri tingkah laku yang merupakan pernyataan manifestasi gejala kesulitan belajar adalah : (1) menunjukkan hasil belajar yang rendah dibawah rata-rata nilai yang dicapai oleh kelompoknya atau di bawah potensi yang dimiliki, (2) hasil yang dicapai tidak seimbang dengan usaha yang telah dilakukan, (3) lambat dalam melakukan tugas-tugas kegiatan belajar, (4) menunjukkan sikap yang kurang ajar seperti acuh tak acuh, menentang, berpura-pura, dusta (5) menunjukkan tingkah laku yang kurang wajar seperti membolos, datang terlambat, tidak tertib dalam kegiatan belajar mengajar, mengasingkan diri, dan lain sebagainya (6) menunjukkan sikap emosional yang kurang wajar, seperti pemurung, mudah tersinggung, pemarah, dan lain-lain.

\section{Penyebab Kesulitan Belajar}

Banyak sudah para ahli yang mengemukakan faktor-faktor penyebab kesulitan belajar dengan sudut pandang mereka masing-masing. Ada yang meninjaunya dari sudut intern anak didik dan ektern anak. Faktor intern adalah faktor yang ada dalam diri individu yang sedang belajar, sedangkan faktor ektern adalah faktor yang ada di luar individu.

Slameto (2013), misalnya melihatnya dari kedua aspek tersebut. Menurutnya faktor-faktor anak didik meliputi gangguan atau kekurangpahaman psiko-fisik anak didik, yakni faktor intern ini akan dibahas menjadi tiga faktor, yaitu faktor jasmaniah, faktor psikologis, dan faktor kelelahan. (1) Faktor jasmaniah, ada dua faktor yakni faktor kesehatan dan cacat tubuh, (2) faktor psikologis , sekurangkurangnya ada tujuh faktor yang tergolong kedalam faktor psikologis yang mempengaruhi belajar. Faktor-faktor itu adalah inteligensi, perhatian, bakat, minat, motif kematangan dan kelelahan. Selain itu ada faktor ektern yang berpengaruh terhadap belajar, dapatlah dikelompokkan menjadi tiga faktor, yaitu: (1) faktor keluarga, siswa yang belajar akan menerima pengaruh dari keluarga berupa : cara orangtua mendidik, relasi antara anggota keluarga, suasana rumah tangga dan keadaan ekonomi keluarga (2) Faktor sekolah, faktor sekolah yang mempengaruhi belajar ini mencakup metode mengajar, kurikulum, relasi guru dengan siswa, relasi siswa dengan siswa, disiplin sekolah, pelajaran dan waktu sekolah, standar pelajaran, keadaan gedung, metode belajar dan tugas rumah (3) faktor masyarakat, membahas tentang 
kegiatan siswa dalam masyarakat, mass media, teman bergaul bentuk kehidupan masyarakat.

Menurut Syah (2000) fenomena kesulitan belajar seorang siswa biasanya tampak jelas dari menurunnya kinerja akademik atau prestasi belajarnya. Namun, kesulitan belajar juga dapat dibuktikan dengan munculnya kelainan perilaku (misbehavior) siswa seperti kesukaan berteriak-teriak di dalam kelas, mengusik teman, berkelahi, sering tidak masuk sekolah, dan sering minggat dari sekolah. Secara garis besar, faktor-faktor penyebab timbulnya kesulitan belajar terdiri atas dua macam, yakni : (1). Faktor Intern, meliputi gangguan atau ketidakmampuan psikofisik siswa seperti yang bersifat kognitif (ranah cipta), yang bersifat afektif (ranah rasa), yang bersifat psikomotor (ranah karsa). (2) Faktor ekstern, meliputi semua situasi dan kondisi lingkungan sekitar yang tidak mendukung aktivitas belajar siswa seperti lingkungan keluarga, lingkungan perkampungan/masyarakat, lingkungan sekolah.

Selain itu faktor-faktor yang bersifat umum tersebut, ada pula faktorfaktor lain yang juga menimbulkan kesulitan belajar siswa. Diantara faktorfaktor lain yang dapat dipandang sebagai faktor khusus ini ialah sindrom psikologis berupa learning disability (ketidakmampuan belajar). Sindrom yang berarti satuan gejala yang muncul sebagai indikator adanya keabnormalan psikis yang menimbulkan kesulitan belajar itu ialah (1) disleksia, ketidakmampuan belajar membaca (2) disgrafia, yakni ketidakmampuan belajar menulis, (3) diskalkulia, yakni ketidakmampuan belajar matematika. Kesulitan belajar siswa yang menderita sindrom-sindrom tadi mungkin hanya disebabkan oleh adanya minimal brain dysfunction, yaitu gangguan ringan pada otak.
Penyebab kesulitan belajar dapat berasal dari faktor internal dan eksternal. Faktor internal meliputi: (1) intelegensi; (2) kurangnya bakat khusus; (3) kurangnya motivasi; (4) situasi pribadi (emosi); (5) faktor jasmaniah; (6) faktor bawaan, seperti buta warna, kidal, dan cacat tubuh. Faktor eksternal meliputi: (1) faktor lingkungan sekolah seperti, sikap guru, cara mengajar, situasi soaial, ruang belajar dan waktu belajar; (2) situasi dalam keluarga siswa, sikap orang tua dan (3) lingkungan sosial (Natawidjaja, 1984).

Perubahan yang terjadi itu sebagai akibat dari kegiatan belajar yang telah dilakukan oleh individu. Perubahan itu adalah hasil yang telah dicapai dari proses belajar. Jadi untuk mendapatkan hasil belajar dalam bentuk "perubahan" harus melalui proses tertentu yang dipengaruhi oleh faktor dari dalam diri individu dan di luar individu. Proses disini tidak dapat dilihat karena bersifat psikologis. Kecuali bila seseorang telah berhasil dalam berhasil , maka seseorang itu telah mengalami proses tertentu dalam belajar. Oleh karena itu, proses belajar telah terjadi dalam diri seseorang hanya dapat disimpulkan dari hasilnya, karena aktivitas belajar yang telah dilakukan.

\section{Murid Lambat Belajar}

Murid lambat belajar (Slow Learner) adalah sekelompok murid di sekolah yang perkembangan belajarnya lebih lambat dibandingkan dengan perkembangan rata-rata teman seusianya. Murid lambat belajar berbeda dengan murid yang prestasi belajarnya rendah (under achiever). Murid lambat belajar perkembangan atau prestasi belajarnya lebih rendah dari rata-rata karena mempunyai kemampuan kecerdasan yang lebih rendah dari rata-rata. Sedangkan murid yang berprstasi rendah (under achiever) prestasi belajarnya lebih rendah dari rata-rata, tetapi kemampuan 
kecerdasannya normal atau mungkin lebih tinggi (Mulyadi, 2010).

$$
\text { Ciri-ciri lambat belajar }
$$

diidentifikasikan sebagai berikut : (1) kemampuan kecerdasan rendah atau di bawah rata-rata, (2) perhatian dan konsentrasinya terbatas, (3) terbatasnya kemampuan untuk menilai bahan-bahan pelajaran yang relevan, (4) terbatasnya kemampuan untuk mengarahkan diri, (5) terbatasnya kemampuan mengabstraksi dan menggeneralisasi yang membutuhkan pengalaman-pengalaman konkret, (6) lambat dalam melihat dan menciptakan hubungan antara kata dan pengertian, (7) sering mengalami kegagalan dalam mengenal kembali hal-hal yang telah dipelajari dalam bahan dan situasi baru, (8) waktu untuk mempelajari dan menerangkan pelajaran cuku lama, akan tetapi tidak dapat bertahan lama dalam ingatannya, (9) kurang mempunyai daya cipta, (10) tidak mempunyai kesanggupan untuk menguraikan, menganalisis atau memecahkan suatu persoalan atau berpikir kritis, (11) tidak mempunyai kesanggupan untuk menggunakan proses mental yang tinggi.

\section{Pengajaran Remedial}

Pengajaran remedial sebagi suatu bentuk khusus pengajaran bertujuan memperbaiki sebagian atau seluruh kesulitan belajar yang dihadapi oleh murid. Perbaikan diarahkan untuk mencapai hasil belajar yang optimal sesuai dengan kemampuan masing-masing melalui perbaikan keseluruh proses belajar mengajar dan keseluruhan kepribadian murid. Tujuan pengajaran remedial sebenarnya tidak berbeda dengan tujuan pengajaran pada umumnya, yaitu agar murid dapat mencapai prestasi belajar sesuai dengan tujuan yang telah ditetapkan. Secara khusus pengajaran remedial bertujuan agar murid yang mengalami kesulitan belajar dapat mencapai prestasi belajar yang diharapkan melalui proses penyembauhan atau perbaikan, baik dari segi proses belajar mengajar maupun kepribadian murid (Mulyadi, 2010).

Pengajaran remedial mempunyai fungsi yang amat pendting dalam keseluruhan proses belajar mengajar. Adapun beberapa fungsi pengajaran remedial tersebut adalah (1) fungsi korektif, (2) fungsi penyesuaian, (3) fungsi pemahaman, (4) fungsi pengayaan, (5) fungsi terapeutik, (6) fungsi akselerasi.

Fungsi korekstif, artinya melalui pengajaran remedial dapat diadakan pembentukan atau perbaikan terhadap sesuatu yang dianggap masih belum mencapai apa yang diharapkan dalam keseluruhan proses belajar mengajar.

Fungsi penyesuaian, artinya agar dapat membantu murid untuk menyesuaikan dirinya terhadap tuntutan kegiatan belajar. Murid dapat belajar sesuai dengan keadaan dan kemampuan pribadinya sehingga memiliki peluang besar untuk memperoleh prestasi belajar yang lebih baik.

Fungsi pemahaman, adalah agar pengajaran remedial memungkinkan guru, murid, dan pihak-pihak lain dapat memperoleh pemahaman yang lebih baik terhadap pribadi murid. Demikian pula murid diharapkan dapat lebih memahami dirinya dan segala aspeknya. Begitu pula guru dan pihak-pihak lainnhya dapat lebih memahami akan keadaan pribadi murid.

Fungsi pengayaan, dimaksudkan agar pengajaran remedial dapat memperkaya proses belajar mengajar. Bahan pelajaran yang tidak disampaikan dalam pengajaran reguler, dapat diperoleh melalui pengajaran remedial.

Fungsi akselerasi, adalah pengajaran remedial yang bertujuan agar dapat mempercepat proses belajar baik dalam arti waktu maupun materi. 
Mulyadi (2010), Pengajaran remedial adalah salah satu tahapan kegiatan utama dalam keseluruhan pola layanan bimbingan dan merupakan rangkaian kegiatan lanjutan logis dan usaha diagnosa kesulitan belajar. Adapun prosedur pengajaran remedial itu sendiri yakni : (1) Penelaahan kembali kasus dengan permasalahannya, (2) Menentukan alternatif pilihan, (3) Layanan Bimbingan dan Konseling, (4) Melaksanakan pengajaran remedial, (5) Mengadakan pengukuran prestasi belajar murid, (6) Mengadakan reevaluasi dan rediagnosis.

Penelaahan kembali kasus dengan permasalahannya. Sasaran pokok langkah ini untuk memperoleh gambaran yang definit fasilitas alternatif tindakan remedial yang direkomendasikan, sesuai dengan sasaran pokok tersebut maka kegiatan di dalam langkah ini difokuskan kepada suatu analisis rasional atau hasil diagnosis yang telah dilakukan atau rekomendasi yang diterima dari pihak lain (guru, petugas BK, dan sebagainya).

Menentukan alternatif pilihan. Sasaran pokok kegiatan yang dilakukan dalam tahapan ini adalah membuat suatu keputusan pilihan alternatif mana yang harus ditempuh berdasarkan pertimbangan rasional yang cermat. Dalam proses pengambilan keputusan ini ada beberapa prinsip-prinsip seperti : (1) efektivitas, dalam arti lebih berorientasi untuk tercapainya tujuan pengajaran remedial yang diharapkan, (2) efisiensi, dalam arti lebih mementingkan usaha dan fasilitas sedikit mungkin dengan hasil yang diharapkan sebanyak mungkin, (3) keserasian.

Layanan bimbingan dan konseling. Sasaran pokok yang hendak dicapai dalam layanan ini adalah terciptanya kesehatan mental kasus, dalam arti ia terbebas dari hambatan dan ketegangan batin untuk kemuadian siap sedai kembali melakukan kegiatan belajar secara wajar dan realistis.
Pada batas-batas tertentu langkah ini dapat ditangani guru, namun mungkin diperlukan bantuan dan kerjasama dengan pihak-pihak lain yang labih ahli (misalnya guru BK, psikolog, dokter, dan lain-lain).

Melaksanakan pengajaran remedial. Sasaran pokoknya adalah tercapainya peningkatan prestasi belajar dan kemampuan penyesuaian diri sesuai dengan kriteria keberhasilan yang ditetapkan.

Mengadakan pengukuran prestasi belajar murid. Setelah pengejaran remedial selesai dilaksanakan, maka perlu dideteksi ada atau tidaknya perubahan pada diri kasus. Oleh karena itu perlu diadakan pengukuran kembali. Hasil pengukurannya akan memberikan informasi seberapa jaug perubahan telah terjadi. Disarankan instrumen yang digunakan pada langkah ini sama dengan yang digunakan pada waktu post test proses belajar mengajar utama.

Mengadakan reevaluasi dan rediagnosis. Hasil penafsiran dan pertimbangan akan menghasilkan tiga kemungkinan kesimpulan, yakni : (1) Menunjukkan peningkatan prestasi dan kemampuan penyesuaian dengan mencapai kriteria keberhasilan minimum seperti yang diharapkan, (2) Menunjukkan peningkatan prestasi dan kemampuan penyesuaian diri, namun belum sepenuhnya memadai, sesuai dengan kriteria keberhasilan minimum yang diharapkan, (3) Belum menunjukkan perubahan yang berarti baik dalam segi prestasi maupun kemampuan penyesuaian diri.

\section{Langkah-Langkah Diagnosis dan Pemecahan Kesulitan Belajar}

Untuk dapat mengidentifikasi siswa yang diperkirakan mengalami kesulitan belajar dapat dilakukan dengan cara : (1) Mengenali kesulitan belajar siswa melalui analisis perilaku, seperti cepat lambatnya 
menyelesaikan tugas, ketekunanserta kehadiran dalam mengikuti pelajaran, partisipasi dalam mengerjakan tugas kelompok, partisipasi dan kontribusi dalam pemecahan masalah, kemampuan kerjasa sama dan penyesuaian sosial, (2) Mengenali kesulitan belajar melalui analisis prestasi belajar, dalam mengidentifikasi siswa yang mengalami kesulitan belajar dapat dilakukan dengan menghimpun, menganalisis, dan menafsirkan data hasil belajar dapat dipergunakan alternatif acuan penilaian yakni penilaian acuan patokan dan penilaian acuan norma (Wardati dan Jauhar, 2011).

Penilaian acuan patokan, dapat dilakukan melalui langkah-langkah : (1) menentukan angka minimal sebagai batas lulus, (2) membandingkan nilai setiap siswa dengan nilai batas lulus yang telah ditetapkan tadi, (3) mencatat atau mengidentifikasi siswa yang memperoleh nilai di bawah nilai batas lulus sebagai siswa yang mengalami kesulitan belajar, (4) menentukan prioritas bantuan berdasarkan besarnya selisih nilai yang diperoleh siswa dengan nilai batas lulus.

Penilaian acuan norma, dapat dilakukan melalui langkah-langkah : (1) mencari atau menghitung nilai rata-rata atau kelompok, (2) menandai siswa yang nilai prestasinya dibawah rata-rata prestasi kelas, (3) menentukan prioritas bantuan.

\section{Langkah-langkah diagnosis} menurut Mulyadi (2010), adalah (1) Identifikasi murid yang mengalami kesulitan belajar, (2) Melokalisasi jenis dan sifat kesulitan belajar, (3) Memperkirakan sebab-sebab kesulitan belajar, (4) Proses pemecahan kesulitan belajar.

Wardati (2011) langkah-langkah dalam melakukan diagnosis yaitu : (1) Melokalisasi letak kesulitan belajar, (2) Menemukan faktor penyebab kesulitan belajar. Langkah-langkah melakukan prognosis, yaitu : (1) memperkirakan alternatif bantuan, (2) menetapkan kemungkinan cara mengatasi kesulitan belajar (3) tindak lanjut.

\section{Layanan Bimbingan Belajar}

Praktik layanan bimbingan belajar kepada peserta didik amatlah penting mengingat tujuan akhirnya dari suatu pembelajaran adalah mengarahkan peserta didik agar mampu belajar mandiri demi kesuksesan peserta didik itu sendiri di masa mendatang. Adapun layanan bimbingan belajar dapat diberikan melalui dua pendekatan yakni (1) pendekatan individual, (2) pendekatan kelompok.

Jenis layanan bimbingan belajar, yakni : (1) Non psikologis melalui perbaikan cara belajar siswa dan perbaikan cara mengajar guru, (2) Psikologis melalui peningkatan motivasi belajar, penanaman prinsip-prinsip belajar.

Kegiatan pendukung dalam bimbingan belajar, yaitu aplikasi intrumentasi, himpunan data, konferensi kasus, kunjungan rumah, alih tangan kasus. Sedangkan materi yang dapat diberikan pada layanan bimbingan belajar antara lain : peningkatan motivasi belajar siswa, peningkatan keterampilan belajar, pengembangan sikap dan kebiasaan belajar yang baik dan pengajaran perbaikan.

Setelah siswa mendapatkan bantuan, guru bimbingan dan konseling atau konselor seyogyanya melaksanakan tindak lanjut layanan bimbimbingan belajar. Seperti : (1) mengetes kembali hasil belajar siswa dalam bidang studi yang dianggap sulit, (2) melakukan wawancara dengan siswa yang bersangkutan untuk mengetahui pendapat siswa tentang kesulitannya, (3) wawancara dengan guru dan orangtua mengenai perubahan yang terjadi, (4) menganalisis hasil belajar yang telah dicapai dan informasi lainnya, (5) observasi kegiatan siswa dalam belajar (Wardati, 2011) 


\section{KESIMPULAN}

Kesulitan belajar pada dasarnya suatu gejala yang nampak dalam berbagai jenis manifestasi tingkah laku baik secara langsung ataupun tidak langsung. Gejala ini akan nampak dalam aspek-aspek kognitif, motoris, dan afektif baik dalam proses maupun hasil proses maupun hasil belajar yang dicapai. Murid lambat belajar (Slow Learner) adalah sekelompok murid di sekolah yang perkembangan belajarnya lebih lambat dibandingkan dengan perkembangan rata-rata teman seusianya. Murid lambat belajar berbeda dengan murid yang prestasi belajarnya rendah (under achiever). Murid lambat belajar perkembangan atau prestasi belajarnya lebih rendah dari rata-rata karena mempunyai kemampuan kecerdasan yang lebih rendah dari rata-rata.

\section{DAFTAR PUSTAKA}

Abdurrahman, Mulyono. (1999). Pendidikan Bagi Anak Berkesulitan Belajar. Jakarta : PT. Rineka Cipta.

Djamarah, Syaiful Bahri. (2011). Psikologi Belajar. Jakarta : PT. Rineka Cipta

Hamalik, Oemar. (2010). Psikologi Belajar dan Mengajar. Bandung : Sinar Baru Algesindo

Khairani, Makmun. (2013). Psikologi Umum. Yogyakarta : Aswaja Pressindo

Makmun, Abin Syamsuddin. (2012). Psikologi Kependidikan Perangkat Sistem Pengajaran Modul. Bandung : PT. Remaja RosdaKarya
Mulyadi, (2010). Diagnosis Kesulitan Belajar dan Bimbingan Terhadap Kesulitan Belajar Khusus. Yogyakarta : Nuha Litera.

Natawidjaja, R. (1984). Pengajaran Remedial. Jakarta: Depdikbud

Slameto. (2013). Belajar dan FaktorFaktor Yang Mempengaruhinya. Jakarta : PT. Rineka Cipta

Syah, Muhibbin. (2000). Psikologi Pendidikan dengan Pendekatan Baru. Bandung : PT. Remaja RosdaKarya

Wlodkowski, Raymond J. (2004). Motivasi Belajar. Jakarta : Cerdas Pustaka

Woolfolk, Anita E. (2004). Mendidik Anak-Anak Bermasalah. Jakarta : Inisiasi Press. 